$\eta^{\prime}$ RFP-2430 $;$

April 19, 1976
RFP-2430

April 19, 1976

\title{
A COMPARATIVE STUDY OF \\ AQUEOUS AND SOLVENT METHODS \\ FOR CLEANING METALS
}

John L. Briggs

Henry A. Goad

Chemistry Research and Development

COMPONENT DEVELOPMENT

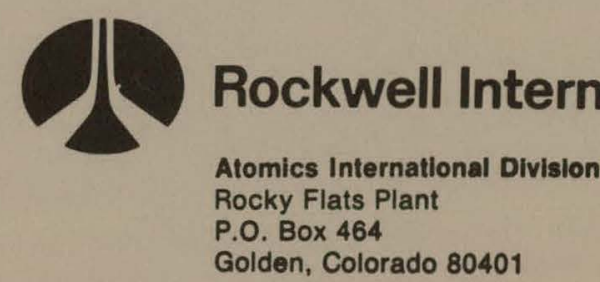

U.S. ENERGY RESEARCH AND DEVELOPMENT ADMINISTRATION CONTRACT E(29-2)-3533 


\section{DISCLAIMER}

This report was prepared as an account of work sponsored by an agency of the United States Government. Neither the United States Government nor any agency Thereof, nor any of their employees, makes any warranty, express or implied, or assumes any legal liability or responsibility for the accuracy, completeness, or usefulness of any information, apparatus, product, or process disclosed, or represents that its use would not infringe privately owned rights. Reference herein to any specific commercial product, process, or service by trade name, trademark, manufacturer, or otherwise does not necessarily constitute or imply its endorsement, recommendation, or favoring by the United States Government or any agency thereof. The views and opinions of authors expressed herein do not necessarily state or reflect those of the United States Government or any agency thereof. 


\section{DISCLAIMER}

Portions of this document may be illegible in electronic image products. Images are produced from the best available original document. 


\section{LEGAL NOTICE}

This report was prepared as an account of work sponsored by the United States Government. Neither the United States nor the Energy Research and Development Administration, nor any of their employees, nor any of their contractors, subcontractors, or their employees, makes any warranty, expressed or implied, or assumes any legal liability or responsibility for the accuracy, completeness or usefulness of any information, apparatus, product or process disclosed, or represents that its use would not infringe privately owned rights.

Printed in the United States of America

Available from the

National Technical Information Service

\section{U. S. Department of Commerce}

Springfield, Virginia 22161

Price: Printed Copy $\$ 4.00$ Microfiche $\$ 2.25$ 


\section{A COMPARATIVE STUDY OF \\ AQUEOUS AND SOLVENT METHODS \\ FOR CLEANING METALS}

John L. Briggs

Henry A. Goad

Chemistry Research and Development COMPONENT DEVELOPMENT

ROCKWELL INTERNATIONAL 
RFP-2430

\section{THIS PAGE}

\section{WAS INTENTIONALLY \\ LEFT BLANK}




\section{CON T E N T S}

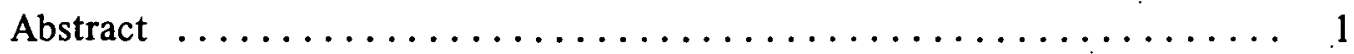

Introduction $\ldots \ldots \ldots \ldots \ldots \ldots \ldots \ldots \ldots \ldots \ldots \ldots \ldots \ldots \ldots \ldots$

Selection of Detergent $\ldots \ldots \ldots \ldots \ldots \ldots \ldots \ldots \ldots \ldots \ldots \ldots \ldots$

Beryllium $\ldots \ldots \ldots \ldots \ldots \ldots \ldots \ldots \ldots \ldots \ldots \ldots \ldots \ldots \ldots$

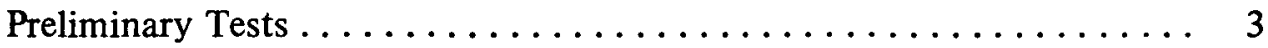

Comparative Cleaning Study $\quad \ldots \ldots \ldots \ldots \ldots \ldots \ldots \ldots \ldots$

Results and Discussion ................... 5

Grit-Blasted Beryllium $\ldots \ldots \ldots \ldots \ldots \ldots \ldots \ldots \ldots \ldots \ldots \ldots$

Comparative Cleaning Study $\quad \ldots \ldots \ldots \ldots \ldots \ldots \ldots \ldots \ldots \ldots \ldots \ldots$

Results and Discussion $\ldots \ldots \ldots \ldots \ldots \ldots \ldots \ldots \ldots \ldots \ldots \ldots \ldots \ldots \ldots$

304L Stainless Steel . . . . . . . . . . . . . . . . . 8

Preliminary Tests $\ldots \ldots \ldots \ldots \ldots \ldots \ldots \ldots \ldots \ldots \ldots \ldots$

Comparative Cleaning Study $\quad \ldots \ldots \ldots \ldots \ldots \ldots \ldots \ldots \ldots$

Results and Discussion ................... 9

Uranium-6.5 Weight Percent Niobium Alloy $\ldots \ldots \ldots \ldots \ldots \ldots \ldots$

Preliminary Tests . . . . . . . . . . . . . . . . . . . . . . 10

Comparative Cleaning Study $\ldots \ldots \ldots \ldots \ldots \ldots \ldots \ldots \ldots \ldots \ldots \ldots$

Unalloyed Uranium $\ldots \ldots \ldots \ldots \ldots \ldots \ldots \ldots \ldots \ldots \ldots \ldots \ldots \ldots$

Comparative Cleaning Study $\ldots \ldots \ldots \ldots \ldots \ldots \ldots \ldots \ldots \ldots$

Results and Discussion ..................... 13

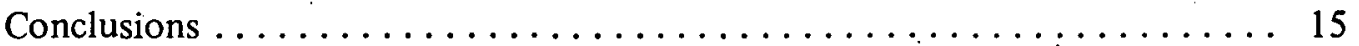

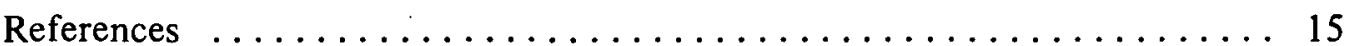




\section{THIS PAGE}

\section{WAS INTENTIONALLY \\ LEFT BLANK}




\title{
A COMPARATIVE STUDY OF AQUEOUS AND SOLVENT METHODS
}

\author{
FOR CLEANING METALS
}

\author{
John L. Briggs and Henry A. Goad
}

\begin{abstract}
Studies were performed to determine the comparative effectiveness of solvent and aqueous detergent methods for cleaning various metals. The metals investigated included $304 \mathrm{~L}$ stainless steel, beryllium, uranium- $6.5 \mathrm{wt} \%$ niobium alloy, and unalloyed uranium $\left({ }^{238} \mathrm{U}\right)$. The studies were initiated in response to governmental regulations restricting the use of somc chlorinated solvents. The results of the studies showed that aqueous detergent cleaning was more effective than solvents, i.e. trichloroethylene and methyl chloroform, for the removal of light industrial soils. The subsequent adoption of aqueous cleaning at this plant has facilitated waste disposal, which contributed to recorded economic savings. The controlled use of aqueous detergents is environmentally acceptable and has decreased the hazards of fire and toxicity that are generally associated with solvents.
\end{abstract}

\section{INTRODUCTION}

Chlorinated solvents have been utilized extensively to clean metals at the Rocky Flats Plant. Historically, ultrasonic vapor degreasing with trichloroethylene has been most frequently used. Perchloroethylene and trifluorotrichloroethane also have been employed to a lesser degree in some metal-cleaning processes.

Because of the volatility of trichloroethylene, solvent vapors escape into the atmosphere through ventilation stacks. Trichloroethylene vapors are subject to photochemical oxidation and have been classified as an air pollutant. ${ }^{1}$ More recently, the possibility that trichloroethylene may be a carcinogenic agent has also been under investigation. ${ }^{2}$ Recent governmental regulations have limited the use of such solvents; cleaning studies have therefore been performed to develop aqueous'cleaning methods to replace the restricted solvents.

\section{SELECTION OF DETERGENT}

An examination of the various types of contaminant soils to be removed indicated that aqueous methods could be effectively employed for production cleaning processes. Water-soluble cutting oils constitute the major surface contaminant to be removed by cleaning. One literature source states that solvent vapor degreasing has limited use for removing cutting fluids because of possible water contamination of trichloroethylene from such cutting fluids. $^{3}$ The aqueous base fluids may also contain soaps that are insoluble in degreasing solvents.

Some light cutting oil and inorganic salt residues from metal cutting fluids are also contaminant soils to be removed. Heavy oils or greases, which require solvent cleaning, are not normally encountered in the production processes at this plant.

Detergent selection was based on previous experience in cleaning processes where combined solventdetergent methods had been employed. Several detergents were examined for cleaning effectiveness; however, the selection of the detergent used in previous processes was based on proven performance. Laboratory analyses of that detergent showed that it is a concentrated liquid soap, composed of alkali ortho phosphates, alkali xylene sulfonate, and alkyl phenol polyoxyethylene condensate. The phosphates are present to maintain the alkalinity of the solution and also to serve as a soil dispersent and water "softener." The alkali xylene sulfonate acts as a hydrotrope to help dissolve organic materials that ordinarily would be only partially soluble in water. The alkyl phenol polyoxyethylene condensate is a surface-active agent that lowers the surface tension of water, enters small voids, and lift particles from the surface of parts being cleaned. The individual and synergistic efficiency of these 
three components constitutes the cleaning effectiveness of the soap solution.

The aqueous detergent cleaning method used for all aqueous cleaning tests.in this report consisted of the following steps:

1. Ultrasonically clean in $15.6 \mathrm{ml} / 1$ detergent solutions at $55 \pm 2{ }^{\circ} \mathrm{C}$ for five minutes.

2. Rinse in constantly overtlowing distilled and deionized water for five minutes.

3. Repeat Step 2 in a separate rinse tank.

4. Dry in forced warm air for five minutes.

5. Handle cleaned metal with clean, white, cotton gloves.

Complete immersion and corrosion tests were conducted to ensure compatibility of the metals with the cleaning solution containing the selected detergent.
Sample specimens of the metals were obtained for the corrosion tests. For the immersion tests, a volume-to-area ratio of 125 milliliters of solution per square inch of sample surface area was used. This conforms to the National Association of Corrosion Engineers standard method. ${ }^{4}$

The samples were surface finished with a 120 grit abrasive paper, rinsed in distilled water, rinsed in acetone, air dried, and weighed to the nearest 0.1 mg. The sample specimens were then immersed in an aqueous solution of the detergent ( $15.6 \mathrm{ml} / \mathrm{l}$ at $55 \pm 2{ }^{\circ} \mathrm{C}$ ) and stored for 10 days. At the end of the test period, the specimens were removed, and loose corrosion products, if any; were rcmoved. After visual inspection, the specimens were reweighed for corrosiun rate determination.

The results of the immersion tests are shown in Table I. No significant corrosion rates were

TABLE I. Compatibility test results of metals with an aqueous detergent

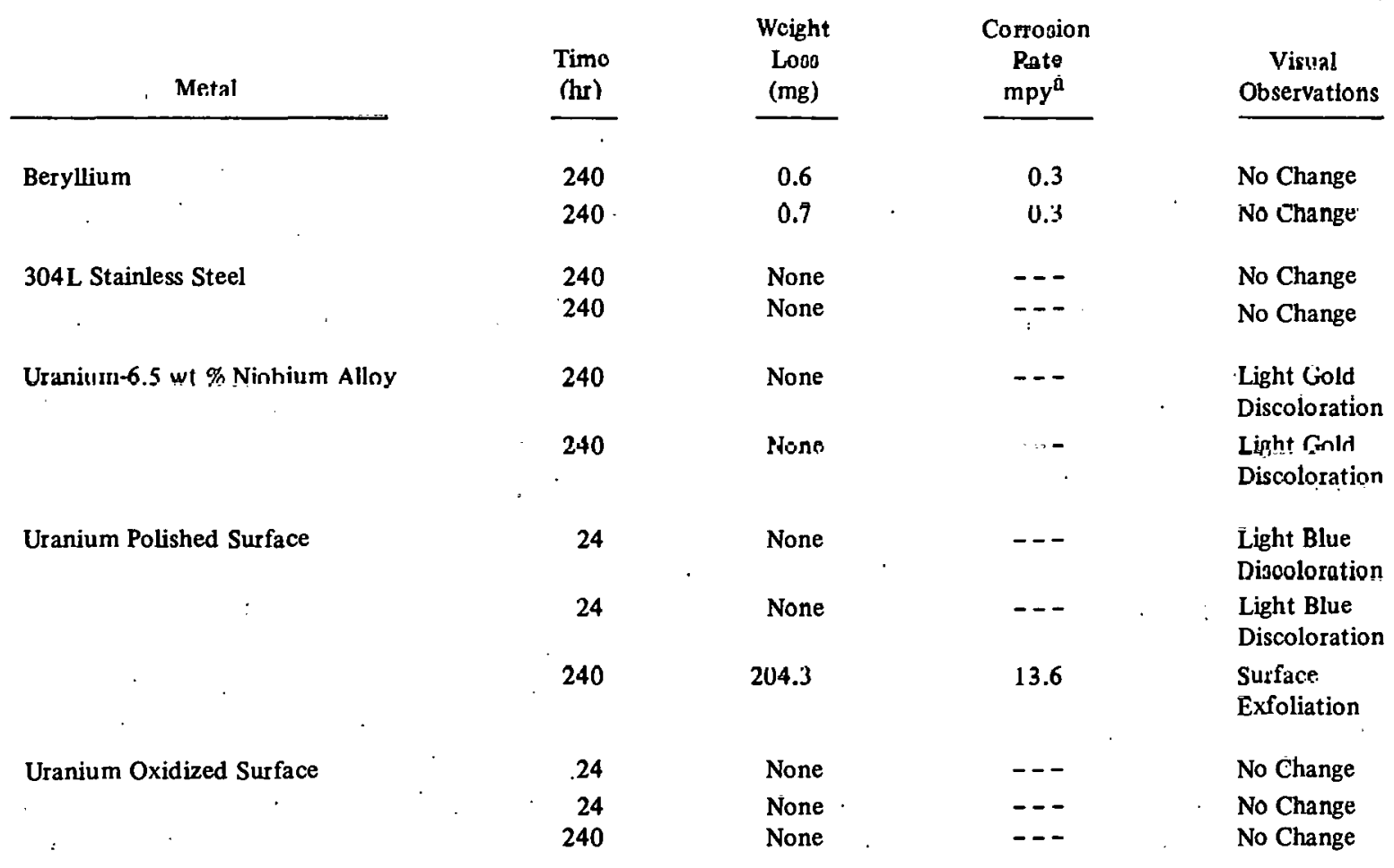

a. mpy-mils penetration per year. 
measured for any of the metals tested, except for the polished uranium after 10 days in storage. The reaction of uranium in water environments has been studied thoroughly, and more detailed information regarding the uranium-water corrosion process is available in the literature. ${ }^{3}$ The formation of uranium oxide films is according to the following equation: ${ }^{4}$

$$
\mathrm{U}+2 \mathrm{H}_{2} \mathrm{O} \rightarrow \mathrm{UO}_{2}+2 \mathrm{H}_{2}
$$

The light oxide discolorations observed on the polished uranium (U) and U-6.5 wt \% niobium $(\mathrm{Nb})$ alloy coupons after the initial 24-hours immersion were equivalent to those resulting from air exposure of uranium and $\mathrm{U}-6.5 \mathrm{wt} \% \mathrm{Nb}$ alloy.

Although slight weight losses were determined for beryllium after immersion in the detergent solution, the calculated corrosion rates would not be considered significant. The normal exposure time for any of the materials during the cleaning process was five minutes, and no adverse effects were observed during the initial hour of immersion for any of the metals tested. It was concluded that all of the metals tested were compatible with the aqueous detergent solution during the exposure time of the cleaning process.

Cleaning studies subsequently were performed with the objective of adopting a standard aqueous method for cleaning beryllium, 304L stainless steel, U-6.5 wt \% $\mathrm{Nb}$ alloy, and unalloyed uranium.

\section{BERYLLIUM}

\section{Preliminary Tests}

Following the announcement of the proposed regulations on solvents, tests were initiated to determine the suitability of aqueous cleaning for all beryllium cleaning processes at Rocky Flats. Residual water tests were conducted with sintered beryllium coupons obtained from a production part. Duplicate sample coupons, uncleaned (controls) and aqueously cleaned, were submitted to mass spectrographic. outgas analysis for determination of water content. Although no quantitative results were obtained, test results showed that all of the water was removed at low temperatures. This indicated that surface, rather than absorbed, water was delected on all of the sample coupons. The bake-out studies also showed no organic or outgas impurities.

Four sets of detergent cleaned and uncleaned, sintered, beryllium sample coupons were then submitted for quantitative. water analysis. The results are shown in Table II. Storage time for all samples (from completion of the aqueous cleaning until analysis) varied from 2 to 48 hours except for Sample 1, Set I. The higher water content, 164.4 $\mu \mathrm{g}$, determined for that sample was possibly caused by incomplete drying during the short in terval ( $<30$ minutes) between cleaning and water analysis. No significant water was detected on any of the other test samples.

Tests were also performed that examined the effectiveness of single aqueous cleaning with a combined aqueous-solvent (trichloroethylene) method for cleaning beryllium production parts.

TABLE II. Beryllium water residue tests ${ }^{\mathrm{a}, \mathrm{b}}$

\begin{tabular}{|c|c|c|c|}
\hline $\begin{array}{c}\text { Set } \\
\text { Number }\end{array}$ & $\begin{array}{c}\text { Sample } \\
\text { Number }\end{array}$ & Sample Treatment & Water Content $(\mu \mathrm{g})$ \\
\hline \multirow[t]{4}{*}{ I } & 1 & Aqueous Cleaned & 164.4 \\
\hline & 2 & Aqueous Cleaned & 5.5 \\
\hline & 3 & No Cleaning (control) & 0.8 \\
\hline & 4 & No Cleaning (control) & 0.2 \\
\hline \multirow[t]{4}{*}{ II } & 7 & No Cleaning (control) & 5.9 \\
\hline & 8 & No Cleaning (control) & 0.1 \\
\hline & 5 & Aqueous Cleaned & 0.0 \\
\hline & 6 & Aqueous Cleaned & 0.0 \\
\hline \multirow[t]{4}{*}{ III } & 9. & No Cleaning (control) & 0.0 \\
\hline & 10 & No Cleaning (control) & 0.0 \\
\hline & 1 & Aqueous Cleaned & 0.1 \\
\hline & 2 & Aqueous Cleaned & 0.0 \\
\hline \multirow[t]{6}{*}{ IV } & 3 & Aqueous Cleaned & 0.0 \\
\hline & 4 & Aquenus Cleaned & 0.1 \\
\hline & 7 & No Cleaning (control) & 0.0 \\
\hline & 5 & Aqueous Clẹaned & $n . n$ \\
\hline & 8 & No Cleaning (control) & 0.0 \\
\hline & 6 & Aqueous Cleaned & 0.1 \\
\hline
\end{tabular}

a. Beryllium sample coupon dimensions were $0.375 \times 0.250 \times 1$ inch.

b. Analyses performed with CEC Type 26-321A Solids Moisture Analyzer@. 
Residue analyses were performed by infrared, emission spectrographic, and atomic absorption techniques. Test results (Table III) demonstrated that the addition of solvent, ultrasonic, vapor degreasing cleaning did not benefit the cleaning process.

\section{Comparative Cleaning Study}

Beryllium coupons that had been exposed to all phases of the production processes were obtained for comparative cleaning tests. Beryllium metal working materials such as perchloroethylene, trifluorotrichloroethane, light grease, inorganic serialization solutions, and oil-soluble dye penetrant test solutions are representative of the production soils to be removed.

Four sets of three beryllium samples coupons were cleaned as follows:

1. Ultrasonic, aqueous detergent cleaned.

2. Ultrasonic, vapor degrease (trichloroethylene).

3. Ultrasonic, vapor degrease (methyl chloroform).

4. Controls (no cleaning).

One sample from each set was then submitted to residue analysis by scanning electron microscopy. The other two samples from each set were submitted to analytical rinse techniques for organic and inorganic residue determinations.

TABLE III. Results of beryllium analytical rinses

\begin{tabular}{|c|c|c|c|c|}
\hline Test & $\begin{array}{l}\text { Beryllium } \\
\text { Part } \\
\text { Number }\end{array}$ & $\begin{array}{c}\text { Hydrocarbòn } \\
\text { C. } H \\
(\mu \mathrm{g} / \text { part })\end{array}$ & $\begin{array}{l}\text { Nonvolatile } \\
(\mu \mathrm{g} / \text { part })^{\mathrm{a}}\end{array}$ & $\begin{array}{c}\text { Residue } \\
\text { Identification }\end{array}$ \\
\hline \multirow[t]{4}{*}{ I. } & Cuntrul (No C & & & \\
\hline & 1 & 580 & 1550 & $\begin{array}{l}\text { Silicates, Lint, } \\
\text { and Hyd marhnns }\end{array}$ \\
\hline & 2 & 720 & 1910 & $\begin{array}{l}\text { Silicates, Lint, } \\
\text { and Hydrocääbons }\end{array}$ \\
\hline & 3 & $<70$ & 860 & $\begin{array}{l}\text { Silicates, Iint, } \\
\text { and Hydrocarbons }\end{array}$ \\
\hline
\end{tabular}

Major Cations Found in the Distilled Water Rinses ${ }^{\mathrm{b}}$
Calcium $\quad$ Potassium Silicon $\quad$ Sodium

II. IJltrasonic Vapor Degrease with trichloroethylene followed by aqucous detcrgent cleaning

$\begin{array}{lll}1 & <70 & <700 \\ 5 & <70 & <700 \\ 6 & <70 & 730\end{array}$

III. Aqueous Detergent

$\begin{array}{llr}7 & <70 & 930 \\ 8 & <70 & <700\end{array}$

\begin{abstract}
Silicates, Lint, and Hydrocarbons
\end{abstract}

Silicates, Lint, and Hydrocarbons

Silicates, Lint, and Hydrocarbons
Silicates, Lint, and Hydrociarbons

Silicates, Lint, and Hydrocarbons
20

20

100

$\begin{array}{rrr}100 & 40 & 500 \\ 100 & 30 & 400 \\ 2 & 100 & 20\end{array}$

$\begin{array}{lrrr}7 & 2 & 100 & 40 \\ 40 & 2 & 250 & 40 \\ 20 & 20 & 40 & 100\end{array}$

a. The $\mathrm{CCL}_{4}$ blank for Tests I, II, and III showed $700 \mu \mathrm{g}$.

b. Results in $\mu \mathrm{g} /$ part by emission spectrograph and atomic absorption. 


\section{Results and Discussion}

Examination of the aqueous- and solvent-cleaned sample coupons by scanning electron microscopy showed several orders of magnitude less residue on the aqueous-cleaned samples than on either of the solvent-cleaned samples. Of special interest was the - detergent removal of soil material from voids or

FIGURE 1. Beryllium metal surface, trichloroethylene cleaned. 900X

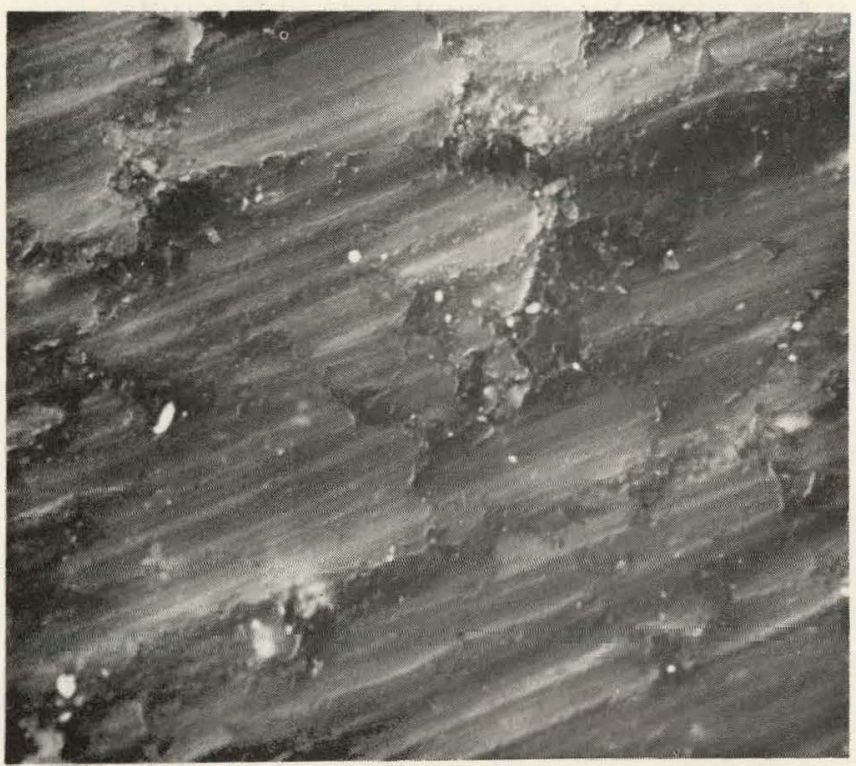

FIGURE 2. Beryllium metal surface, aqueous detergent cleaned. 900X

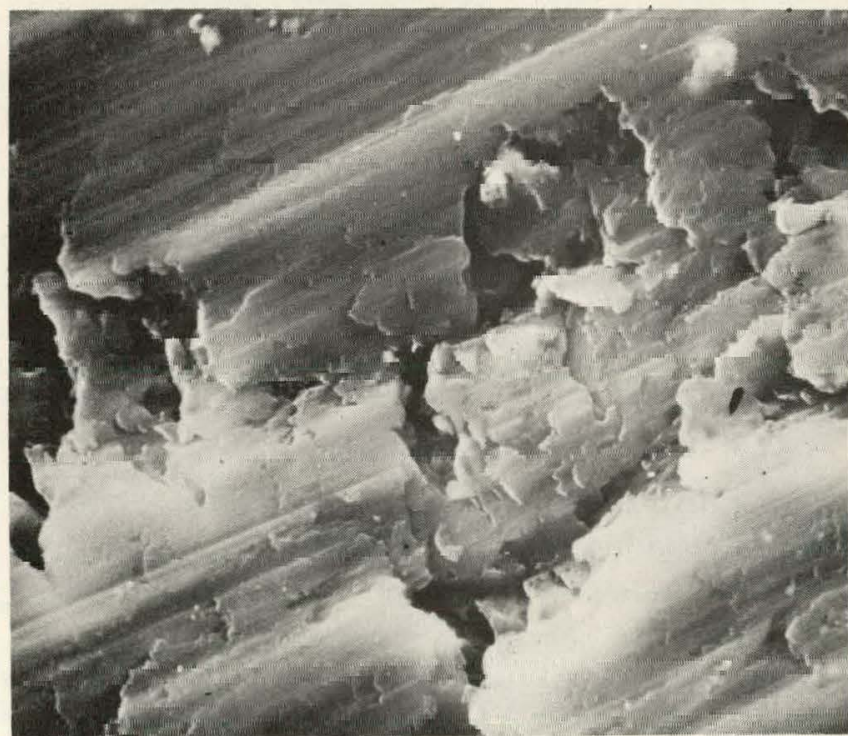

crevices that was not apparent on the control or the solvent-cleaned samples (Figures 1 and 2).

Chlorides were identified by nondispersive X-ray only on the trichloroethylene-cleaned sample coupons. Photomicrographs of the chloride particles are shown in Figures 3 and 4.

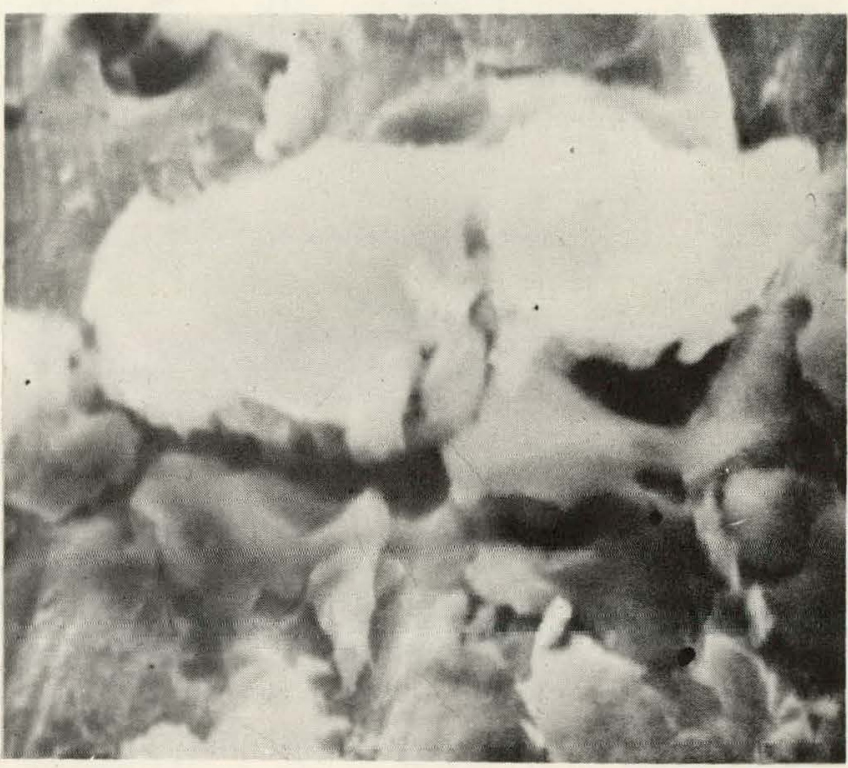

FIGURE 4. Chloride particle, $\mathrm{X}$-ray image of Figure 3. 5000X

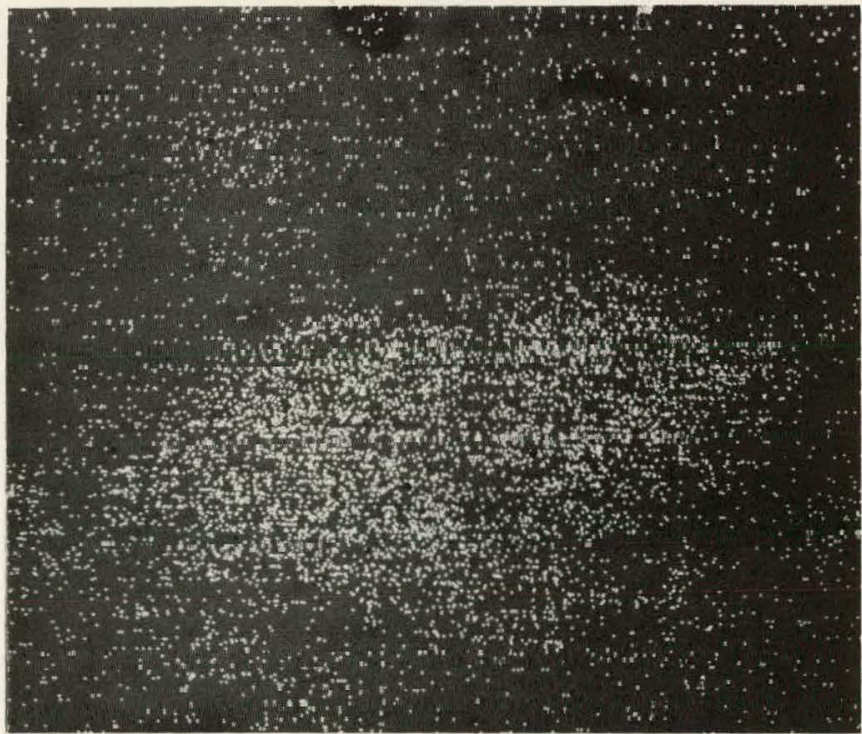


Analytical rinses on sample coupons were performed with distilled water and carbon tetrachloride. The distilled water rinses were examined for residue by emission spectrograph, atomic absorption, total organic carbon, and specific ion electrode techniques. No organic carbon or significant cations were detected. No chlorides were detected for the aqueous- or trichloroethylene-cleaned samples. Chlorides were detected $\left(4 \mu \mathrm{g} / \mathrm{in}{ }^{2}\right)$ for the methyl chloroform-cleaned sample.

The carbon tetrachloride rinses were analyzed by infrared spectrophotometry for residual oils or greases. No significant organic contaminants were detected on any of the solvent or aqueous cleaned coupons.

\section{GRIT-BLASTED BERYLLIUM}

In one special application of beryilium parts, the beryllium metal surface is grit-blasted with aluminum oxide. Because of reported microcracking, apparently related to ultrasonically induced stresses, the use of ultrasonic agitation for cleaning has been restricted. The cleaning currently is performed by solvent methods (trichloroethylene immersion plus vapor degreasing; no ultrasonics). Comparative cleaning tests were conducted to determine the effectiveness of aqueous cleaning for cleaning grit-blasted beryllium.

\section{Comparative Cleaning Study}

Reject, grit-blasted, beryllium production parts were obtained for the cleaning tests. One gritblasted beryllium part was cleaned by the specified cleaning method of immersion in circulating trichloroethylene for four minutes followed by vapor degreasing (three-to-four minutes)-no ultrasonics. The parts then were air-dried for 15 minutes. A second grit-blasted beryllium part was cleaned by the aqueous-detergent method previously described. After cleaning, the beryllium parts were rinsed with distilled water for inorganic residue analysis by emission spectroscopy and specific ion electrode techniques. Analytical rinses with carbon tetrachloride were also performed for organic residue determination by infrared spectrophotometry.
Grit-blasted beryllium coupons that had been cleaned with trichloroethylene (with and without ultrasonics) and aqueous detergents (with and without ultrasonics) were submitted to scanning electron microscopy for comparative residue analyses and evidence of microcracking.

Two more grit-blasted beryllium coupons (one cleaned with the specified trichloroethylene method and one cleaned ultrasonically with an aqueous detergent) were submitted to Auger electron spectroscopy for comparative residue results.

\section{Results and Discussion}

No chlorides were detected by specific ion electrode on the aqueous-cleaned (ultrasonic) parts; however, $4.4 \mathrm{ppm}$ of chlorides were detected in the rinse water of the solvent- (no ultrasonics) cleaned parts. Elemental analysis of the rinse water by emission spectroscopy showed no significant differences between the two cleaning methods.

Analysis of the carbon tetrachloride rinses by infrared techniques showed less hydrocarbons [0.58 $\mu \mathrm{g} / \mathrm{in}^{2}{ }^{2}$ oil residues $\left.(\mathrm{C}-\mathrm{H})\right]$ for the aqueous cleaning than for the solvent-cleaned part $\left(1.3 \mu \mathrm{g} / \mathrm{in}^{2}{ }^{2}\right)$. Less carbonyl $\left(0.09 \mu \mathrm{g} /\right.$ in. $^{2}$ oxidized oil residues $(\mathrm{C}=\mathrm{O})$ ] was detected for the aqueous-cleaned parts than for the solvent method $\left(0.24 \mu \mathrm{g} /\right.$ in. $\left.^{2}\right)$.

Analysis of grit-blasted beryllium coupons by the scanning electron microscope (SEM) showed that the use of ultrasonic agitation with both aqueous and solvent cleaning removes more of the aluminum oxide grit-blasted material than simple immersion methods. Less aluminum oxide was detected on the coupons cleaned with the ultrasonic aqueous delergent method than for any of the other test coupons (Figures 5-7).

Comparative analysis by Auger electron spectroscopy showed high carbun (probably from trichloroethylene) and iron concentrations on the solvent-cleaned beryllium coupon. Equivalent amounts of nitrogen and aluminum were detected for both the solvent- and aqueous-cleaned coupons. 


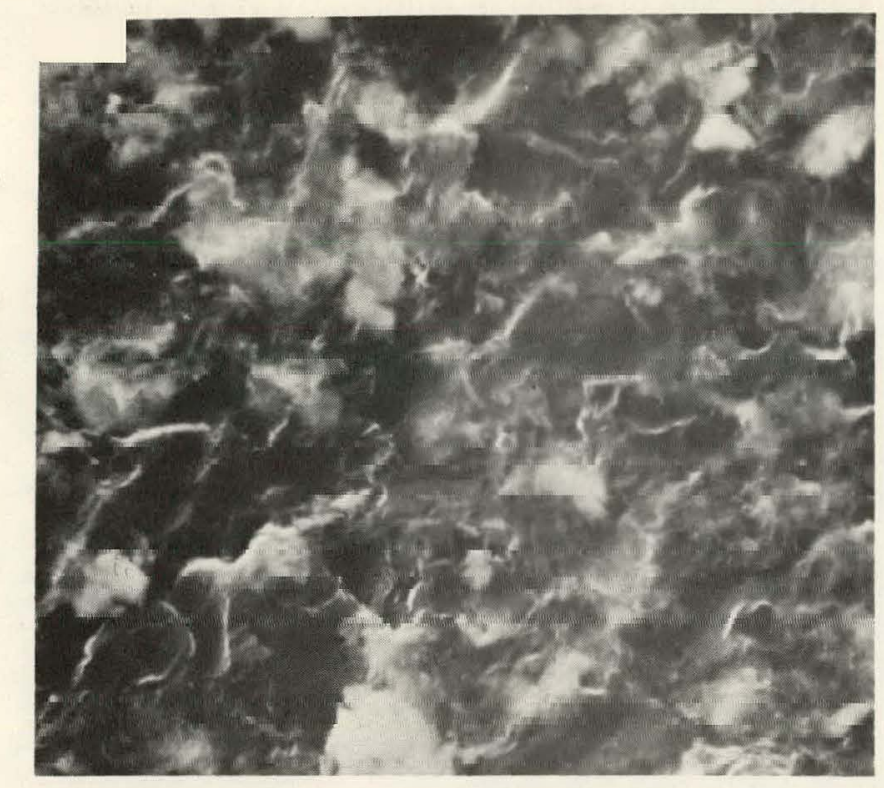

FIGURE 5. Grit blasted beryllium, trichloroethylene cleaned. No ultrasonics. 2800X

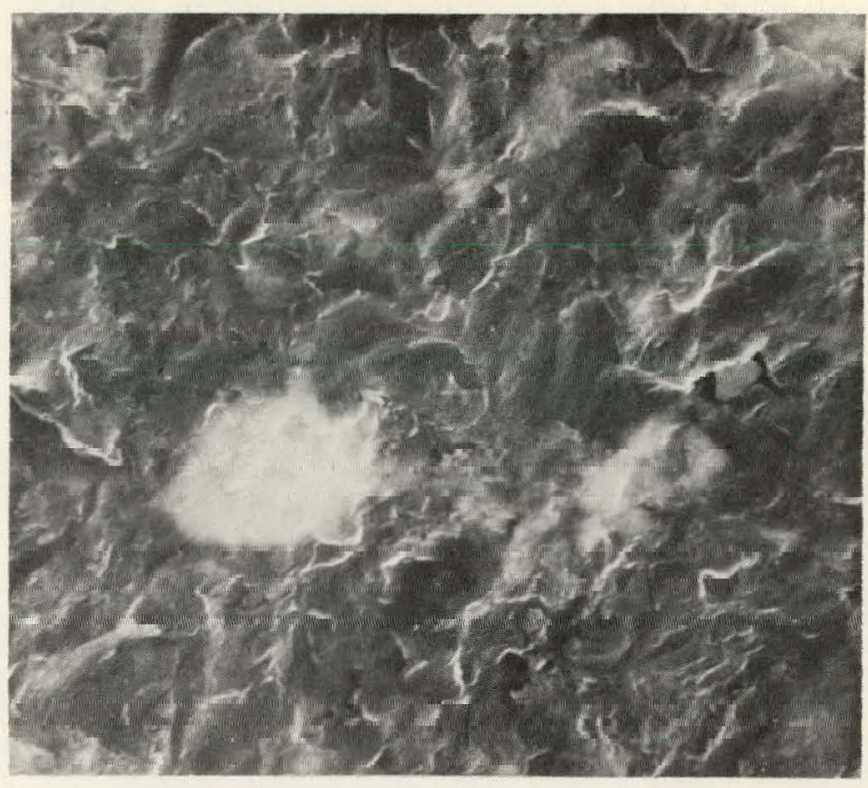

FIGURE 6. Grit blasted beryllium, aqueous detergent cleaned with ultrasonics. $2800 \mathrm{X}$

FIGURE 7. Aluminum oxide particles, nondispersive X-ray image of Figure 5.

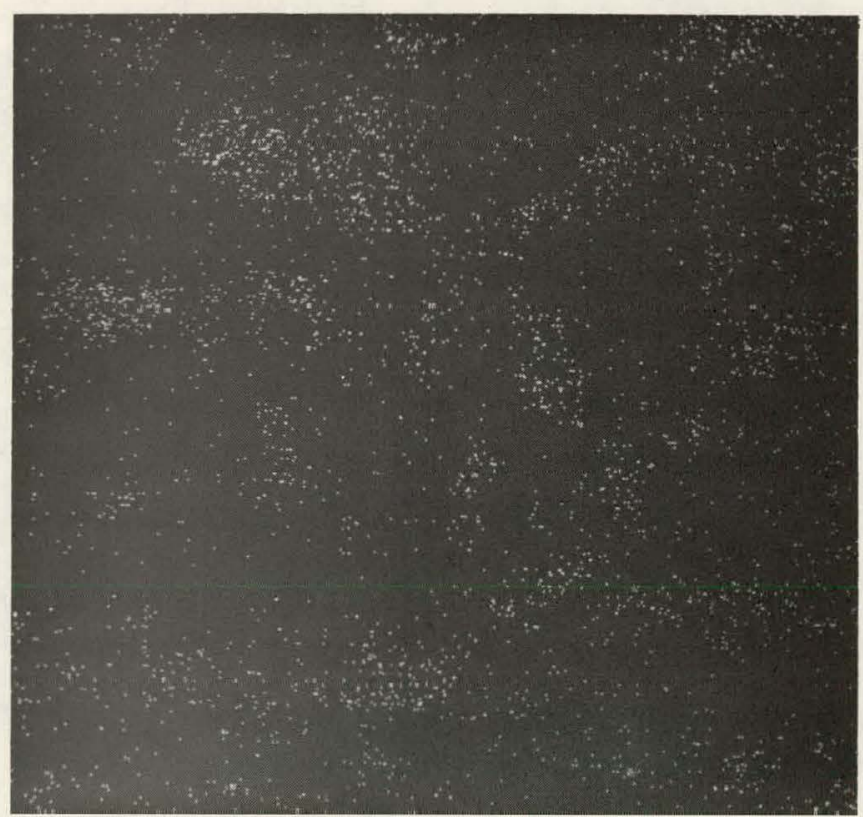


Although no microcracking was exhibited in any of the ultrasonic cleaning tests, the possibility of ultrasonically induced cracking may not be precluded on the basis of these studies, which were concerned primarily with cleaning effectiveness.

\section{L STAINLESS STEEL}

\section{Preliminary Tests}

One preliminary study was initiated when corrosive residues were detected on welded stainless steel parts. The joining process consisted of electron beam welding of $304 \mathrm{~L}$ stainless steel to 309 stainless steel. A thin film of visible chloride residues with associated pitting was apparent in the residue areas.

\section{Analysis of the rejected parts by scanning electron} microscopy identified high chloride concentrations in the pitted areas. Photomicrographs showing the chloride-contaminated areas are shown in Figures
8 and 9. The presence of chlorides was also confirmed by electron microprobe and Auger electron spectroscopy techniques.

The stainless stcel parts had been cleaned before welding with trichloroethylene (ultrasonic vapor degreasing) and after electron beam welding, by ultrasonic vapor degreasing with trifluorotrichloroethane. One or both of the solvents was the only possible source of the contaminant chlorides. Solvent cleaning was replaced by the aqueous detergent method, which eliminated the chloride contamination.

\section{Comparative Cleaning Study}

Comparative aqueous-solvent cleaning studies were then performed to verify the aqueous method for 304L stainless steel cleaning. Sample coupons of $304 \mathrm{~L}$ stainless steel (0.036-in. thick $\times 2.250$ in.
FIGURE 8. 304L stainless steel, trichloroethylene cleaned. $1700 \mathrm{X}$

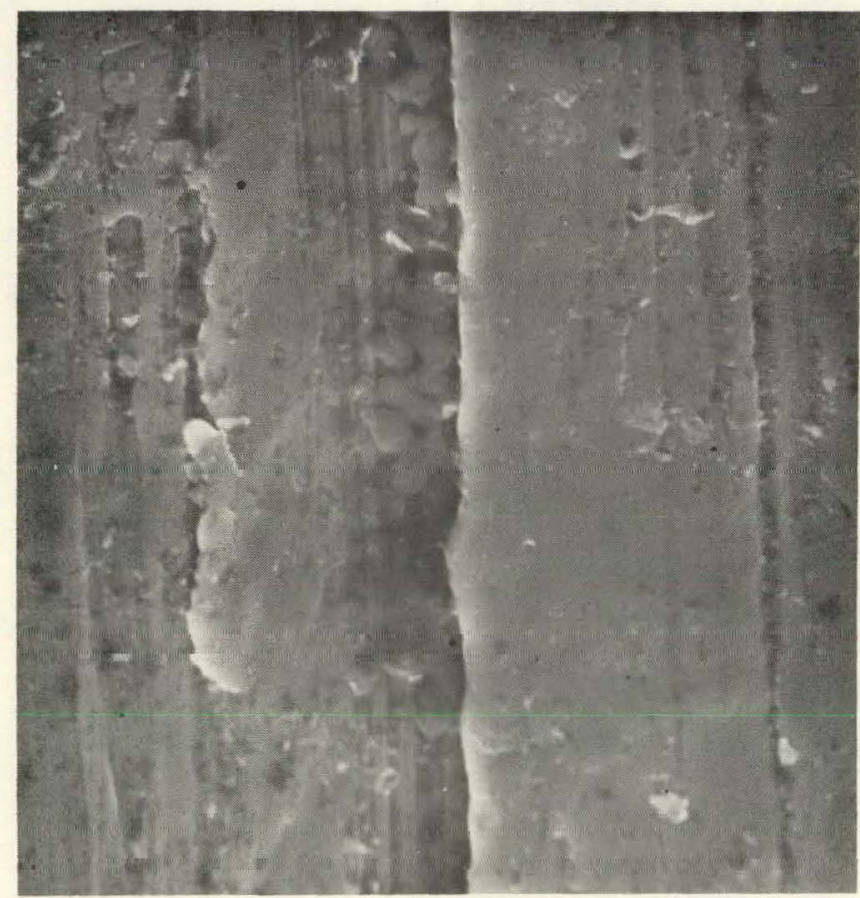

FIGURE 9. Chloride, X-ray image of Figure 8. 1700X

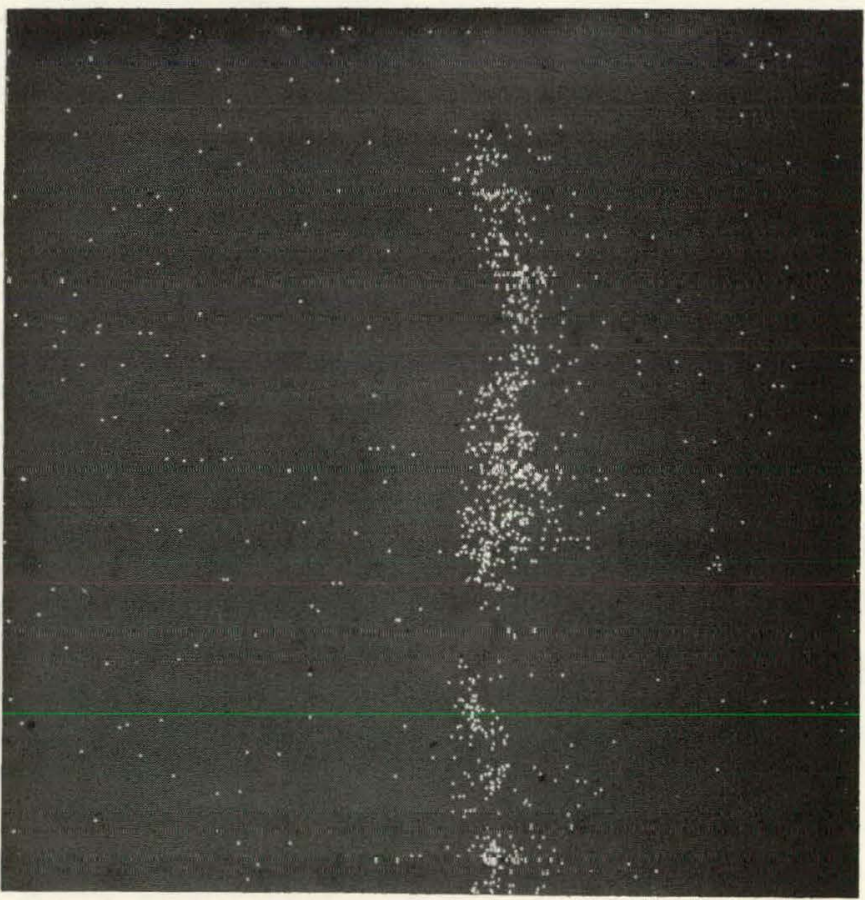


diameter) were obtained for the tests. The sample coupons were surface finished with 120 grit abrasive, rinsed in distilled water, and air dried.

The coupons were then immersed in a mixture of machine oils, trichloroethylene, trifluorotrichloroethane, and water, which simulated typical soils to be removed. After exposure to the simulated mixture, the coupons were wiped; they then represented "dirty" coupons. Aqueous cleaning was performed in a laboratory ultrasonic cleaner with beaker distilled water rinses. Solvent (trichloroethylene) cleaning was performed in production, ultrasonic, vapor-degreasing equipment.

After cleaning by both methods, duplicate sample coupons were evaluated for cleaning effectiveness by scanning electron microscopy and by analytical rinse techniques for residue.

\section{Results and Discussion}

No significant difference in residues was detected by infrared spectrophotometry in any of the carbon tetrachloride rinses, and no significant cations were detected in the distilled water rinses. Chloride $\left(1.4 \mu \mathrm{g} /\right.$ in. $\left.^{2}\right)$ was detected, however, by specific ion electrode on the solvent-cleaned samples, whereas no chlorides were detected for the aqueous-cleaned samples.

The chloride residues associated with chlorinated solvents have been detected on other solvent-cleaned metals (i.e., beryllium and U-6.5 wt \% Nb alloy) and can initiate severe corrosion pitting with stainless steel. ${ }^{5-7}$ Examination of the solvent- and aqueouscleaned sample coupons by scanning electron microscopy showed less residues on the aqueouscleaned surfaces (Figures 10 and 11).

Production parts and 304L stainless steel coupons were also precleaned with the aqueous detergent to determine the effects, if any, on weld integrity. After cleaning, the stainless steel was welded and brazed by various joining processes. The joints were then inspected by ultrasonic and radiographic techniques for porosity, microcracks, and inclusions. The rejection rate for the preweld, aqueous-cleaned
FIGURE 10. Stainless steel, aqueous detergent cleaned. $460 \mathrm{X}$

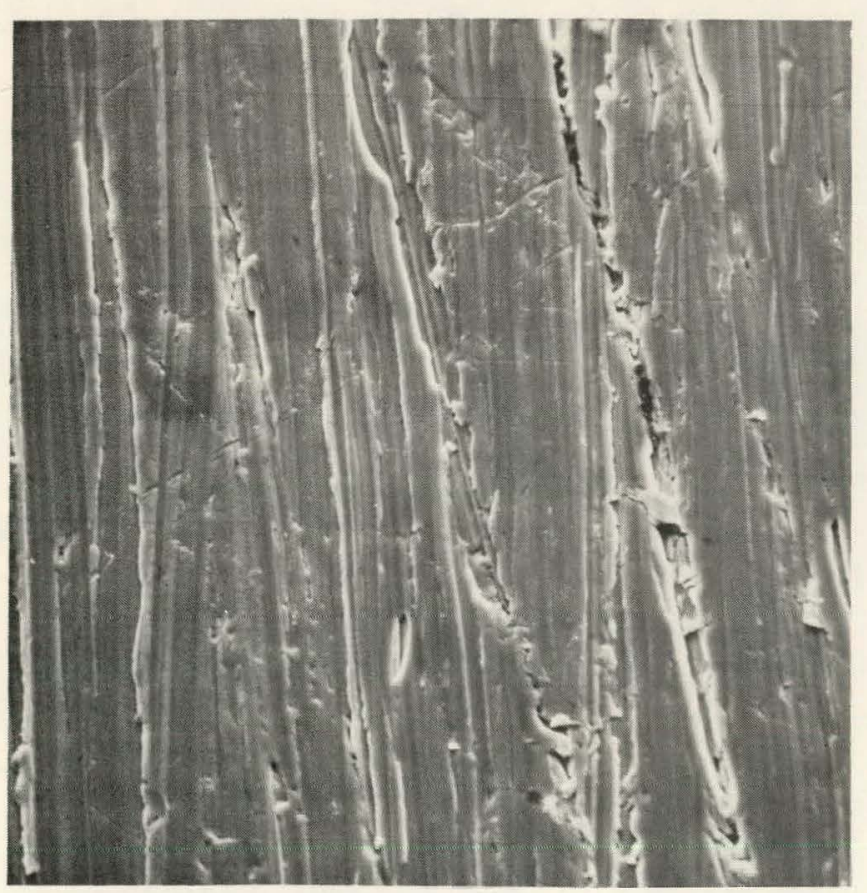

FIGURE 11. 304L stainless steel, trichloroethylene cleaned. $460 \mathrm{X}$

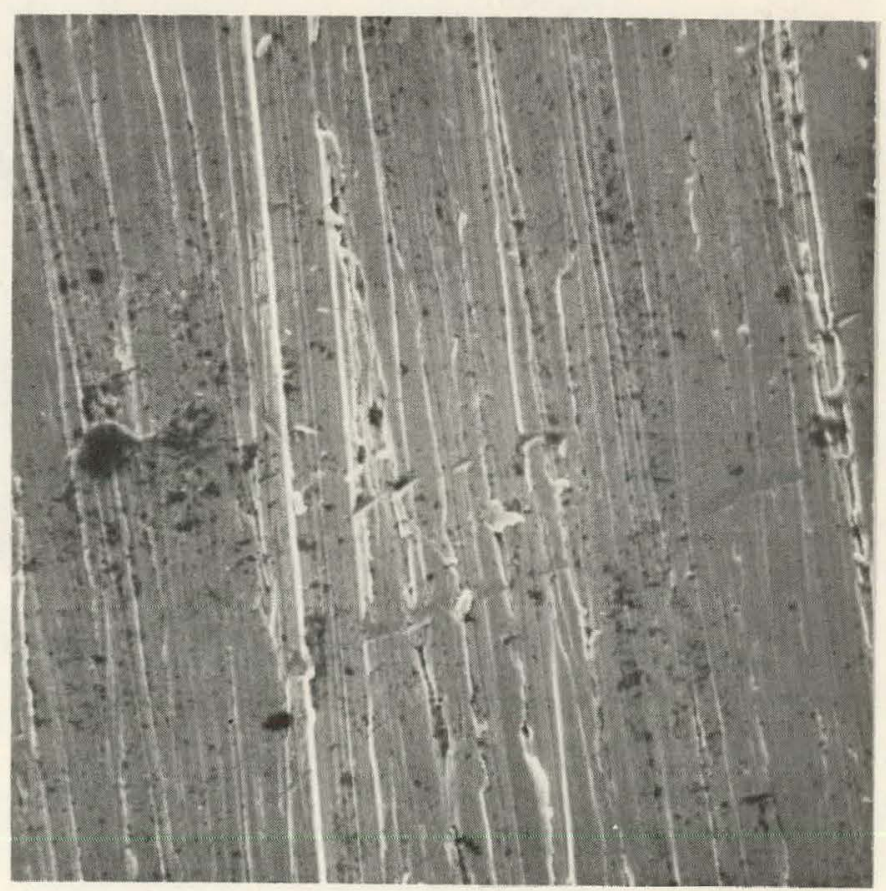


joints was slightly lower then the normal rejection rate for preweld solvent-cleaned joints.

Final cleaning proof tests for beryllium and 304L stainless steel were performed on 10 production parts (two sets of five parts each). All of the 304L stainless steel and beryllium components of one set were cleaned with the aqueous method for mass spectrographic comparison of outgas products. This was also done with an equal number of solventcleaned parts. The total quantity of outgas products from the aqueous-cleaned parts was significantly lower than for those that were solvent cleaned (Table IV). Of interest was the fact that lower levels of water were detected in the aqueous cleaned parts than on the solvent cleaned parts.

\section{URANIUM-6.5 WEIGHT PERCENT NIOBIUM ALLOY}

\section{Preliminary Tests}

A study of U-6.5 wt \% Nb alloy final cleaning was performed to evaluate a dual (solvent plus aqueous

TABLE IV. Mass spectrographic outgas analyses of aqueous-cleaned and solvent-cleaned parts ${ }^{\mathrm{a}}$

\begin{tabular}{lcc}
$\mathrm{H}$ & $\begin{array}{c}\text { Trichloroethylene } \\
\text { Cleaning } \\
(\mu \mathrm{g} / \text { part })\end{array}$ & $\begin{array}{c}\text { Aqueous Detergent } \\
\text { Cleaning } \\
(\mu \mathrm{g} / \text { pal })\end{array}$ \\
\cline { 2 - 2 } $\mathrm{CH}_{4}$ & 227 & 162 \\
$\mathrm{CO}$ & 13 & 16 \\
$\mathrm{~N}_{2}$ & 4 & 2 \\
$\mathrm{NO}$ & 87 & 58 \\
$\mathrm{O}_{2}$ & 26 & 26 \\
$\mathrm{H}_{3} \mathrm{O}$ & 5 & 2 \\
$\mathrm{CO}_{2}$ & 222 & 154 \\
$\mathrm{HC}^{\mathrm{b}}$ & 394 & 143 \\
$\mathrm{DIA}^{\mathrm{c}}$ & 159 & 72 \\
$\mathrm{C}_{2} \mathrm{HCl}_{3}$ & 362 & 36 \\
\hline
\end{tabular}

a. Average of five parts for each cleaning method

b. Hydrocarbons

c. Diisopropylamine (solvent inhibitor) detergent) cleaning method. The solvent-detergent method employed trifluorotrichloroethane (Freon113) for precleaning prior to aqueous cleaning.

The solvent precleaning was necessary because two production metalworking materials were not being removed by aqueous cleaning.

One of the materials, a silicone grease lubricant, was used to seal the part to a vacuum pot check during machining operations. Precleaning with Freon-113 prior to aqueous cleaning was necessary to remove the silicone grease. The combined solvent-aqueous detergent cleaning was not effective, however, for removing a permanent marking pen ink used during inspection processes.

Petrolatum proved to be a suitable substitute for the silicone grease and was effectively removed by aqueous cleaning. It was also determined that the marking pen ink (xylene solvent base) was effectively removed by wiping with xylene, methyl chloroform, trichloroethylene, or kerosene immediately following inspection processes.

Tests were next performed to determine whether solvent precleaning could be eliminated. Sample coupons of U-6.5 wt \% $\mathrm{Nb}$ alloy were obtained for diagnostic cleaning studies. The sample coupons were surface finished with 120 grit abrasive paper, rinsed in distilled water, and air-dried. Duplicate sample coupons were then treated and cleaned in the manner shown in I'able V. After cleaning, the sample coupons were submitted to scanning elcctron microscopy and Auger electron spectroscopy for surface residuc analysis.

No significant difference in hydrocarbon (oil) residue was detected by scanning electron microscopy for any of the test coupons that were final cleaned with heated $\left(55+2{ }^{\circ} \mathrm{C}\right)$ detergent solutions. Sample Coupon 14 (heated detergent cleaning, no solvent) also exhibited no significant hydrocarbon residues (Figure 12). High levels of hydrocarbon residues were detected for Sample 29 , which was cleaned at room temperature as shown in Figure 13. This sample coupon displayed too much organic contamination to photograph at a magnification higher than $50 \mathrm{X}$.

The effectiveness of elevating the detergent temperature was also determined by Auger electron spectroscopy. The sample coupons that were final 
RFP-2430

TABLE V. Cleaning test parameters uranium- 6.5 weight percent niobium alloy

\begin{tabular}{l}
$\begin{array}{c}\text { Sample } \\
\text { Identification }\end{array}$ \\
\hline $1-2$ (control) \\
$3-4$ \\
$5-6$ \\
$7-8$ \\
$13-14$ \\
$27-28$
\end{tabular}

$29-30$

Treatment
Surface finish with 120 grit paper
Surface coat of silicone grease
Surface coat of silicone grease
Surface coat of Petrolatum
Surface coat of Petrolatum
Surface coat of Petrolatum

Surface coat of Petrolatum

\begin{tabular}{l} 
Cleaning Process \\
\hline Aqueous detergent clean \\
Wipe with perchloroethylene. \\
Aqueous detergent clean \\
Wipe with Freon-113. \\
Aqueous detergent clean \\
Wipe with Freon-113. \\
Aqueous detergent clean \\
Aqueous detergent clean \\
Wipe with Freon-113. \\
Aqueous detergent clean \\
(room temperature) \\
Wipe with methyl chloroform. \\
Aqueous detergent clean \\
(room temperature)
\end{tabular}

a. Detergent temperature $-55 \pm 2{ }^{\circ} \mathrm{C}$,

b. Detergent temperature $-23 \pm 2{ }^{\circ} \mathrm{C}$ (room temperature).

\section{3}

FIGURE 12 . Uranium- 6.5 weight percent niobium alloy, aqueous cleaned (elevated temperature). 500X
12

FIGURE 13. Uranium- 6.5 weight percent niobium alloy, aqueous cleaned (ambient temperature). 50X

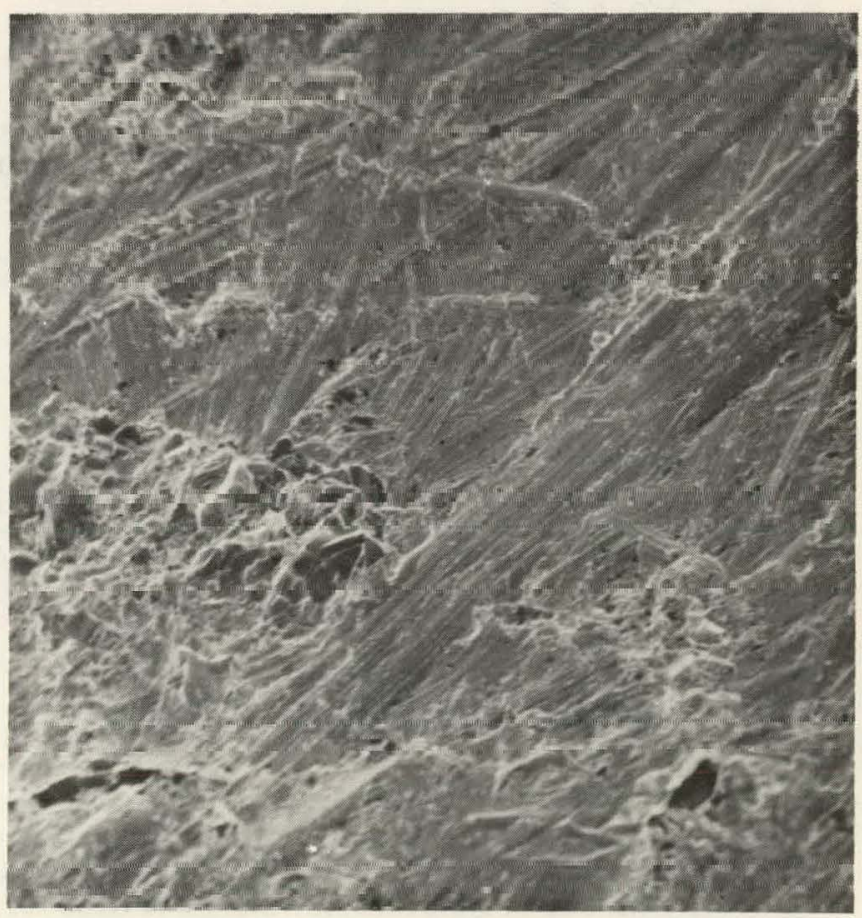


cleaned in heated $\left(55^{\circ} \mathrm{C}\right)$ detergent showed generally less hydrocarbon residues than did the sample coupons cleaned with detergent at room temperature. Silicon residues were detected by Auger spectroscopy on all of the silicone-coated samples after cleaning. No silicone was detected on the petrolatum-coated samples.

\section{Comparative Cleaning Study}

Three U-6.5 wt \% Nb alloy sample coupons were examined for surface oxidation after exposure to the elevated detergent temperature. Prior to cleaning, all of the sample coupons were surface finished with 120 grit abrasive paper and rinsed with distilled water. 'Ihe results of analyses by $\mathrm{X}$-ray diffraction are shown in Table VI.

\begin{tabular}{|c|c|}
\hline Sample Treatment & $\begin{array}{l}\text { Oxide } \\
\text { Ihickness }\end{array}$ \\
\hline Control (no cleaning) & $74 \AA$ \\
\hline $\begin{array}{l}\text { Aqueous Detergent Cleaned } \\
\text { at } 23 \pm 2^{\circ} \mathrm{C} \text { (room } \\
\text { temporature) }\end{array}$ & $53 \AA$ \\
\hline $\begin{array}{l}\text { Aqueous Detergent Cleaned } \\
\text { at } 5.5 \pm 2{ }^{\circ} \mathrm{C} \text {. }\end{array}$ & $89 \AA$ \\
\hline
\end{tabular}

No significant difference in oxide formation was detected, and no weight changes were measured. Although phase changes occur in the alloy to $55^{\circ} \mathrm{C}$, they are reversible, and no problems would be expected because of exposure to that temperature.

Comparative cleaning studies were then performed to confirm the suitability of the one-step, elevatedtemperature detergent cleaning. Three production parts were cleaned for comparative residue analyses by analytical rinse techniques. The results are shown in Table VII.

Any marking pen ink marks on the reject parts were removed by wiping with methyl chloroform prior to the cleaning tests. The results of the tests showed typically high residue levels on the control part. Part 2, which was cleaned solely with the solvent, showed less residues than the control part but somewhat higher levels than Parts 3 and 4. Both Parts 3 (solvent-aqueous cleaned) and 4 (aqueous-detergent cleaned) showed no significant contamination with inorganic and organic residues.

\section{UNALLOYED URANIUM}

All stainless steel and beryllium parts (with the exception of grit-blasted beryllium) are currenlly being cleaned by aqueous methods. One final

TABLE VII. Residue analyses of uranium- 6.5 weight percent niobium parts

\begin{tabular}{|c|c|c|c|c|c|c|c|}
\hline \multirow[b]{2}{*}{ Part Number } & \multirow[b]{2}{*}{ Clcaning Method } & \multirow{2}{*}{$\begin{array}{l}\text { Hydrocarbon }{ }^{\mathrm{a}} \\
\text { Residue } \\
\left(\mu \mathrm{g} / \text { in. }^{2}\right) \\
\end{array}$} & \multicolumn{5}{|c|}{ Inorganic Residue, ${ }^{\mathrm{b}}\left(\mu \mathrm{g} / \mathrm{in}^{2}{ }^{2}\right)$} \\
\hline & & & Sodium & Calcium & Potassium & Phosphate & Chlorine \\
\hline 1 & $\begin{array}{l}\text { Control (no } \\
\text { cleaning) }\end{array}$ & 55 & 0.4 & 0.03 & 0.3 & $<0.1$ & 0.37 \\
\hline 2 & $\begin{array}{l}\text { Freun-113 } \\
\text { cleaning }\end{array}$ & 0.17 & 0.2 & 0.03 & 0.1 & $<0.1$ & $<0.15$ \\
\hline 3 & $\begin{array}{l}\text { Freon- } 113 \\
\text { followed by } \\
\text { aqueous detergent } \\
\text { at } 23 \pm 2{ }^{\circ} \mathrm{C}\end{array}$ & 0.13 & 0.02 & $<0.01$ & 0.02 & $<0.1$ & $<0.10$ \\
\hline 4 & $\begin{array}{l}\text { Aqueous detergent } \\
\text { at } 55 \pm 2{ }^{\circ} \mathrm{C}\end{array}$ & 0.09 & 0.02 & $<0.01$ & 0.02 & $<0.1$ & $<0.10$ \\
\hline
\end{tabular}

a. Hydrocarbon [C-H $\left.\left(\mu \mathrm{g} / \mathrm{in.}^{2}\right)\right]$ analysis by infrared spectrophotometry.

b. Inorganic residues analyses by atomic absorption and specify ion electrodes analyses.

c. Hand-cleaned with Freon-113, first rinse in Freon-113, second rinse in Freon-113. 
solvent cleaning process has been continued, however, that combines the cleaning of stainless steel, beryllium, and unalloyed uranium parts. Cleaning studies therefore were conducted to determine whether the use of aqueous cleaning methods could be extended to include the uranium parts in this combined operation.

\section{Comparative Cleaning Study}

Uranium $\left({ }^{238} \mathrm{U}\right)$ sample coupons were used for all of the cleaning tests. Since the production parts exhibited an adherent surface oxide when received for final cleaning, the cleaning studies were performed on similar oxidized $\left(\mathrm{UO}_{2}\right)$ sample coupons. In addition, identical cleaning tests were performed on duplicate sample coupons from which the surface oxide had been removed by polishing with 120 grit abrasive paper. After polishing, the samples were rinsed in distilled water and air-dried. All of the analytical tests were performed within 48 hours after polishing to minimize the effects of atmospheric oxidation.

The polished and oxidized uranium sample coupons were pretreated by immersion in a mixture of perchloroethylene ( $25 \mathrm{vol} \%$ ), carbon tetrachloride (25 vol \%), and light machine oil (50 vol \%). The oil and solvent mixture simulated production cutting oil and residue to be removed by the cleaning processes. The uranium parts are typically covered with a thin film of oil when received. The oil film is removed by a preliminary solvent (methyl chloroform) vapor degreasing prior to further production processing. This initial cleaning was also performed on the sample test coupons. The cleaning test parameters and methods for analyzing residues are shown in Table VIII.

Polished and oxidized control sample coupons ( $1 \mathrm{a}$, 3a, 5a, 7a, 9a, and 11a) were also submitted to all of the analytical techniques shown in Table VIII. The control samples were pretreated with oil-solvent contamination; preliminary solvent cleaning was not performed. The control samples were given aqueous cleaning only for comparative residue analyses. In addition, an oxidized uranium sample coupon (no pretreatment or cleaning) was submitted for mass spectrographic gas product analyses.

\section{Results and Discussion}

No significant difference in residues was detected by scanning electron microscopy for any of the oxidized sample coupons examined. The surfaces of the oxidized coupons showed some pitting, which existed prior to the solvent and aqueous cleaning processes.

The oxide thickness on three of the oxide sample coupons was measured by X-ray diffraction techniques. The results are shown in Table IX.

The polished uranium sample coupon that was aqueous-cleaned displayed a much cleaner surface (Figure 14) than the solvent-cleaned sample (Figure 15). The removal of matter from voids and crevices on the aqueous-cleaned metal surfaces is not apparent on the solvent-cleaned sample. The greater capacity of aqueous cleaning to remove residues from voids in the metal surfaces has also been observed in cleaning studies of beryllium production parts.

Analytical rinses with carbon tetrachloride were performed on solvent and aqueous cleaned sample coupons. This was done to permit hydrocarbon residues detection by infrared spectroscopy. No significant contamination with organic residues was detected for any of the sample coupons. Analytical rinses of the sample coupons with distilled water for inorganic residues were examined by emission spectrographic and specific ion electrode techniques. No significant inorganic residues were detected on any of the solvent- or aqueous-cleaned samples.

Mass spectrograph analysis showed significantly lower total organic outgas products (oil contamination) for the aqueous-cleaned samples than for the solvent-cleaned samples. In addition, solvent 
TABLE VIII. Unalloyed uranium cleaning test parameters and methods

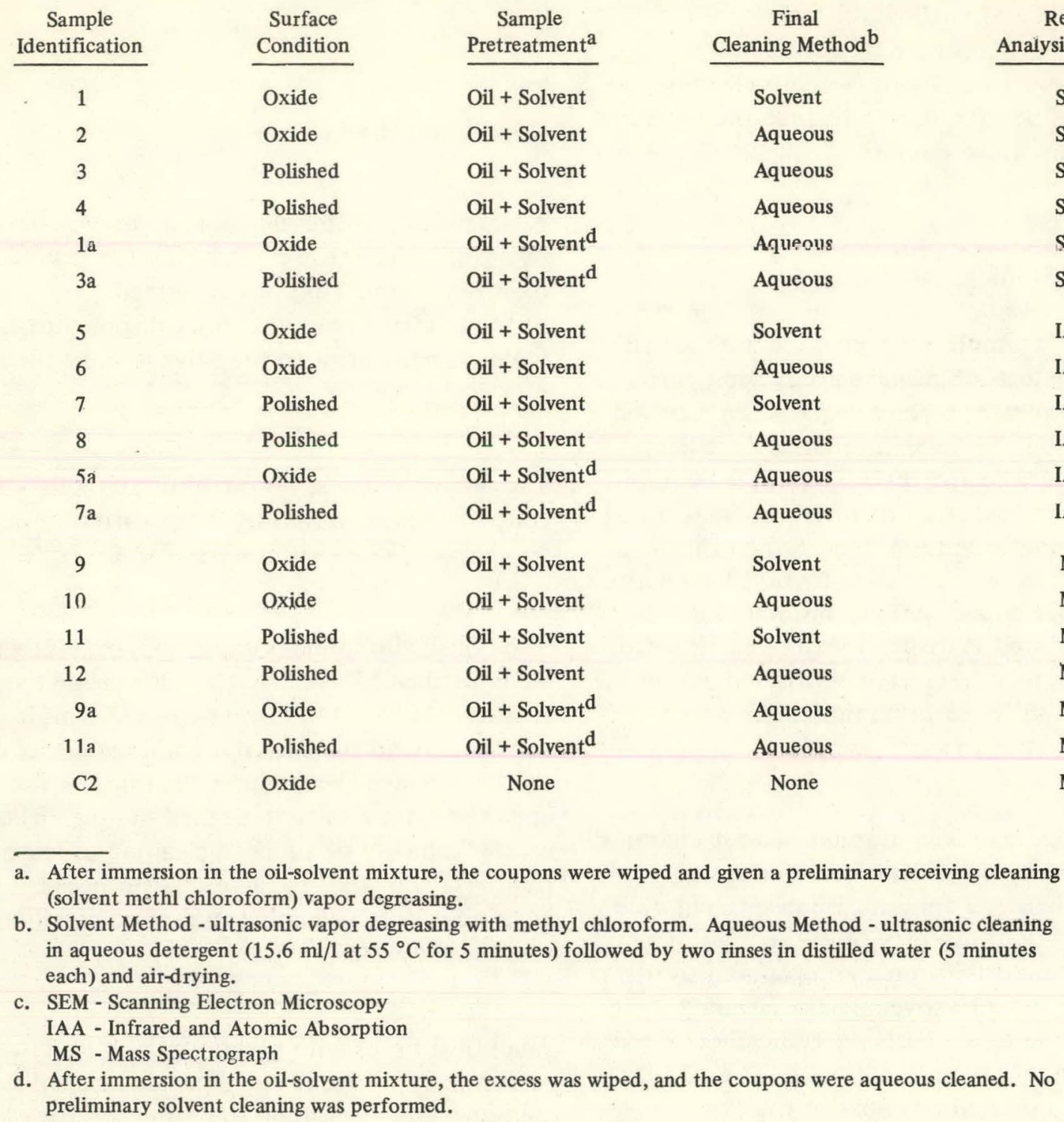

TABLE IX. Unalloyed uranium sample coupon oxide* thickness

\begin{tabular}{|c|c|}
\hline Sample Number & Oxide Thickness \\
\hline 1a & $2230 \AA$ \\
\hline 1 & $2135 \AA$ \\
\hline 2 & $2160 \AA$ \\
\hline
\end{tabular}

*Oxide identified as $\mathrm{UO}_{2}$. and solvent-inhibitor residues were detected on the solvent-cleaned samples; these contaminants would not be present after aqueous cleaning.

No significant difference was measured for levels of outgassed water for either the aqueous- or solvent-cleaned sample coupons. Both cleaning methods showed less water contamination than the control (no cleaning) sample, which indicated 


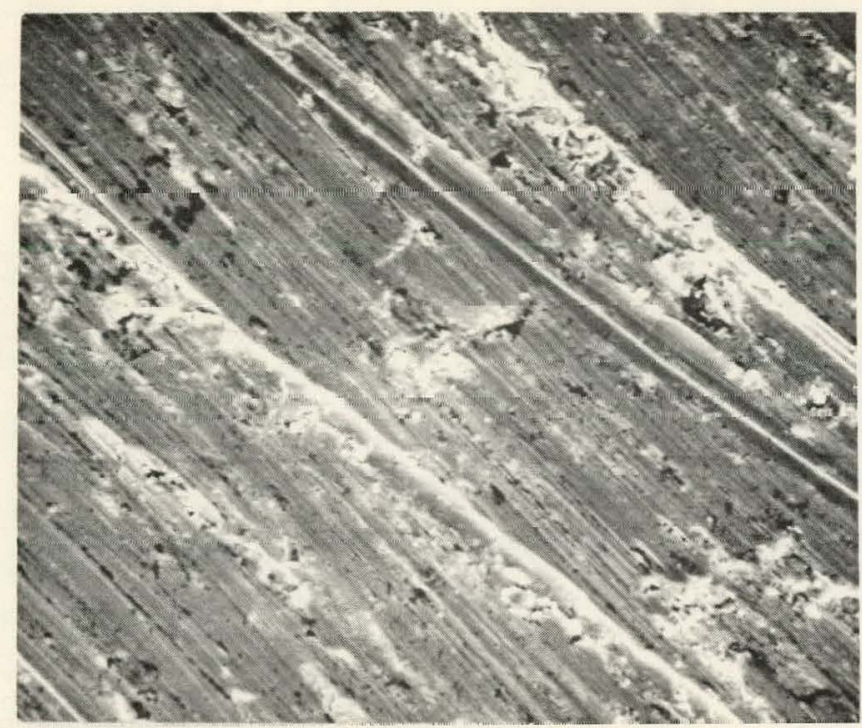

FIGURE 14. Polished unalloyed uranium, solvent (methyl chloroform) cleaned. 550X

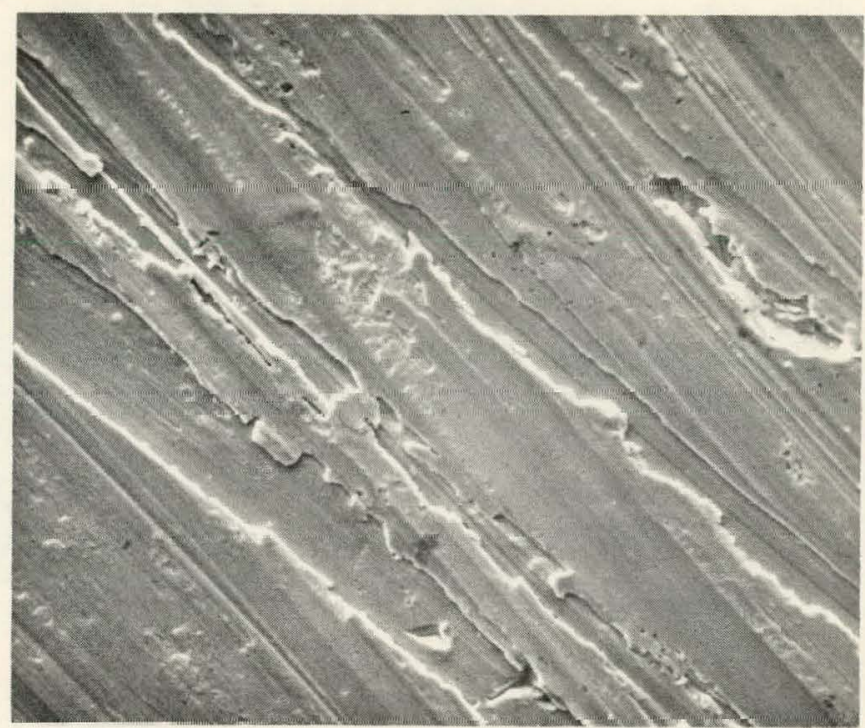

FIGURE 15. Polished unalloyed uranium, aqueous cleaned. $580 \mathrm{X}$ water absorption does not occur during the aqueouscleaning process. Somewhat higher levels of contaminant outgas products were detected for all of the oxidized sample coupons compared to the polished coupons. These higher levels probably resulted from the greater surface area (porosity) of the oxidized samples.

\section{CONCLUSIONS}

1. A standard aqueous detergent cleaning method has been developed that cleans beryllium, 304L stainless steel, U-6.5 wt \% Nb alloy, and unalloyed uranium as well as or better than ultrasonic solvent vapor degreasing.

2. No evidence of any significant amount of absorbed residual water has been detected for any of the metals exposed to the aqueouscleaning environments.

3. Aqueous detergent cleaning effectively removes contaminant chloride residues that are acquired in ultrasonic solvent (trichloroethylene) cleaning methods.

4. Corrosion tests show that the selected detergent is compatible with all of the metals tested.

\section{REFERENCES}

1. Environmental Protection Agency. Federal Register, Volume 38, Number 214, Part II. November 7, 1973.

2. R. J. Seltzer. "Reactions Grow to Trichloroethylene Alert." Chemical Engineering News. p. 11. American Chemical Society, Easton, Pennsylvania. May 19, 1975.

3. Metals Handbook. 8th Edition, Volume 2 . p. 339. American Society for Metals, Metals Parts, Ohio. 1964.

4. "Test Method: Laboratory Corrosion Testing of Metals for the Process Industries." NACE Standard TM-01-69. Huston, Texas. 1969.

5. H. H. Uhlig. The Corrosion Handbook. p. 166. John Wiley \& Sons, Inc., New York. 1951.

6. M. G. Fontane. Corrosion Engineering. pp. 50-51. McGraw Hill Book Company, New York. 1967.

7. F. L. LaQue and H. R. Copson. Corrosion Resistance of Metals and Alloys. p. 380. Reinhold Publishing Corporation, New York. 1963. 
RFP-2430

\section{THIS PAGE WAS INTENTIONALLY LEFT BLANK}

